\title{
RESHAPING BANKING INDUSTRY THROUGH DIGITAL TRANSFORMATION
}

\author{
Vladimir Mirković ${ }^{1 *}$ \\ Jelena Lukić, ${ }^{2}$ \\ Vesna Martin ${ }^{3}$ \\ ${ }^{1}$ Economists Association of \\ Belgrade, Serbia, \\ ${ }^{2}$ Modern Business School, \\ Belgrade, Serbia \\ ${ }^{3}$ National Bank of Serbia, \\ Belgrade
}

\begin{abstract}
:
Development and breakthrough of information and communication technologies in all spheres and aspects significantly changed the way of conducting business. Digital transformation is not an option for organizations, no matter of their size, industry, maturity, number of employees, customers and so on. In order to survive and stay competitive in digital age, organizations need to be agile, flexible, ready to adjust on rapid changes in the business environment and create new values for customers. Traditional banks recognized all benefits and potentials reflected in usage of new digital technologies. Their focus is shifted on simplification of providing service on anytime in any place to potential customers. Through adoption of Big Data concept and customer-centric approach, banks are among those organizations which widely use new technologies in digital age with the aim to create and sustain competitive advantage. Banking industry is obviously changed and significantly reshaped by digitalization process. In this paper is presented the case of DBS bank from Singapore, which made an extraordinary turnover in its business toward digital transformation and positioned itself as the leading digital bank in the world..
\end{abstract}

\section{Keywords:}

digital transformation, organizational agility, banking industry, Big Data, FinTechs

\section{INTRODUCTION}

Globalization processes and adjustment of bank's operations toward new business models represent one of the main features in contemporary banking industry. At the same time, the role of banks experienced serious changes, in regards that usual understanding of banking business relied on traditional loan and deposit transactions nowadays remains enriched with new forms of relationship between banks and customers. Those new relations between banks and customers are based on existence and development of new technological solutions which significantly change modern banking business.

Business processes and models in digital age reshape banking industry imposing adjustment of banks in all segments that are earlier recognized as a source of their regular lucrative engagement (Lukić \& Mirković, 2018). As the other organizations, banks should react promptly on rapid changes in the business environment caused by the impact of digital transformation and create new opportunities through capturing market niches.

\footnotetext{
Correspondence:

Vladimir Mirković 


\section{DIGITAL TRANSFORMATION: LITERATURE} REVIEW

The manner in which technology is used by people is completely changed (Stone, 2019). Digital technologies change: attitudes, behavior, expectations, the way of communication, decision making process etc. All these changes transformed the way in which organizations conduct their operations and functions (Bankewitz, Aberg \& Teuchert, 2016). Digital transformation is not an option for organizations; on the contrary it is an imperative if they intend to maintain competitiveness on the market (Andriole, Cox \& Khin, 2018). Regardless of various views on digital transformation, in which is stated that:

- digital transformation means "use of technology in order to radically improve performance or reach of enterprises" (Westerman et al., 2011);

- digital transformation is "ongoing digital evolution both strategically and tactically" (Mazzone, 2014); or

- digital transformation "establishes new technologies based on the Internet with a fundamental impact on the society as a whole" (Pricewaterho use Coopers, 2013);

It is clear that digital transformation changes the whole business landscape of any organization, no matter of its industry, size, maturity, number of markets etc.

Most organizations rethink the practical meaning of the quote "being digital organization". A lot of them have already initiated digital projects without success, while some of them hope that digital technologies are just a one-off trend. However, banks could not be classified in neither of the mentioned groups, because they carefully plan their approach to digital transformation. That approach means that digital transformation of banks is not related to purchasing new technologies, but on finding new opportunities, markets, chances and the new ways of conducting operations. The key results that organizations could expect after digital transformation are (Herbert, 2017):

- Increase in revenues: higher marker share, occupying new market niches, lower costs of maintaining existing and attracting new customers;

- Higher competitive advantage: better products or services in comparison with competitors or innovative products or services;

- Capability to "do more with fewer resources": higher efficiency, coordination, using of all advantages that organization creates.

Digital transformation is much more than investment. It is commitment to implementation of new technologies and commitment to the adjustment process across the whole organization (Hyatt, 2018).

For adequate response on changes in business environment in digital age, it is very important for enthusiasm to be built-in throughout organization and that the vast majority of employees clearly understand how much change is necessary. Certainly, rapid changes in organizations at the same time have a lot of barriers, but the crucial challenge for leaders and managers is establishing and nurturing the organizational structure, which is agile, flexible, responsive, open and innovative (Hughes, 2017). Likely, the key point in understanding of digital transformation role in organizations is the establishing of the novel "mindset" throughout organization, which is not an easy job. Digital transformation could not be observed as one-off job or activity, since is almost impossible at the very beginning of the process to predict the effect of changes on all operations and activities.

An organization which applies new technologies, should pay special attention on employees, whose duty is to handle with technologies in the right way. When starting their digital journey, organizations must employ new employees such as: Data Scientist, Data Engineers, Data Architects etc. (Lukić, 2016; Lukić, Salkić, Ostojić, 2018). On the other hand, in some cases, digitalization results in layoffs and staff reductions at some positions due to intelligent systems, chatbots, automatization of some processes and activities. All stakeholders (managers and employees) should be involved in the process of understanding how organizations functions when they experience digital transformation. In that manner they create conditions for comprehensive insight and overcoming ongoing organizational difficulties during digital transformation, which is the optimal path for future development (Mirković et al., 2019).

\section{DIGITAL TRANSFORMATION IN BANKING INDUSTRY}

To maintain its competitiveness level, traditional banks should become more agile, accept innovative culture and become more focused on simplification of providing services on anytime in any place to potential clients (Mirković \& Lukić, 2015). To achieve all that goals, banks found out new support reflected in modern Big Data technologies. For many organizations, especially banks, Big Data technologies represent the new source of competitive advantage (Lukić, 2016).

Big Data era opened the whole spectrum of innovative possibilities for the interaction between banks and clients, imposing to banks a new challenge - to become integral part of clients' life and to adjust its business toward satisfaction of clients' needs and desires (Dudić et al., 2018). Lukić (2017) emphasized that Big Data should not be observed through the aspect of data size. It is rather the matter of data attributes which make them robust to work with traditional technologies and tools on the one hand, and data that are useful for new value creation on the other hand. Modern operations consider the mix of 
traditional data with all new data collected from various sources (called Big Data). Collection of data in described manner could possible lead to new models and analytical tools for prediction of clients' future behavior and their assessment.

With digital transformation of main business operations, banks made a big step toward optimization of its business. Although, optimization and modernization of business in banks are bearing different kind of risks and some of them are already recognized, whilst new types of risk will arise as a consequence of digital transformation. It will significantly change the perception of risk and operational realization of business processes in banks (Dudić et al., 2018). Reporting requirements make banking business slow and complicated due to more formalization and paperwork instead of establishing more efficient business. Concept of Big Data provides the opportunity for improving efficiency of banking business with simultaneous fulfillment of reporting requirements. In Dudić et al. (2018), the author points out the necessity for successful implementation of Big Data concept in banks as a tool for avoiding robustness, which is imposed by regulatory reporting requirements.

The modern phase of financial industry development is marked with significant rise in the segment of financial technologies (so-called FinTechs). FinTech innovations attract a lot of attention in public, but simultaneously there exists a risk that whole concept of FinTechs could be compromised due to an even small, unintentional error. In that sense, Republic of Serbia took several actions in order to regulate this segment, especially taking into account the fact that 2016 was announced as the "year of entrepreneurship" with focus on FinTech start-up companies.

Due to entrance of FinTechs, the major issue emerges in dilemma whether banks and FinTechs will be competitors or collaborators on financial markets. FinTechs have some competitive advantages, such as (Mirković, 2017):

- they are more agile than traditional banks;

- they have no obligation toward competent national authorities (e.g. central banks) regarding regulatory reporting;

- $\quad$ they are innovative and flexible when it comes to adjustment on variable environment;

- $\quad$ they are capable to occupy those market niches which are abandoned or forgotten by traditional banks or traditional banks did not recognize the potential of certain market niches; and

- they satisfy existing needs of customers on the new way, significantly different than traditional banks, making the average customer became a "fan of information-communication technologies".
On the other side, traditional banks are those with incomparable higher financial strength in comparison with usually small, start-up FinTechs. Although FinTechs satisfy the needs in the different way, there will still be a certain segment of customers which could be described as "admirers of traditional products". Also, FinTechs could be observed as a good motivator for banks and at the same time a collaborator in the global game well known as "innovate or disappear".

With the revolution caused by smartphones and online culture, people could access information almost anywhere and anytime. Using a mobile phone as a mean of multiple communications, payment and borrowing, small firms could reach consumers more easily. In addition, smartphone technology provides a unique insight into the habits of its users through sophisticated analytical data processing tools, which were previously available only to large companies. Also, the field in which new market participants, such as FinTechs, could seriously threaten major market participants would be the field of payments. The emergence of bitcoin as an electronical mean of payment redefined the regular functioning of payment and settlement systems, representing the possible alternative to traditional banking payment operations (Mirković et al., 2016). By increasing digitization in all spheres of life and changing people's habits, a new generation growing in the digital world expecting quick, simple, secure and easily accessible pay-per-click services, and that is the segment where small players (i.e. technology-oriented companies) could occupy a significant part of the market.

Modern information-communication technologies are widely accepted throughout the banking industry worldwide, contribute to the digitalization process globally. Technology itself created conditions that had an impact on business areas through time and made the adjustments to continuous changes and innovations easier. Introduction of new technologies in banks provide higher efficiency and lower costs accompanied with larger use of contemporary communication channels between banks and clients. Digital banking is directly dependent upon telecommunication services with the focus on service availability at any time $(24 \times 7)$ at any place (multifunctional devices, ATMs, mobile phones, tablets, desktop computers etc.) in the right time.

Almost all commercial banks in Serbia have banking applications for smartphones and advanced applications for electronic banking (e-banking), while a large number of banks have mobile banking (m-banking) services in their offer. Digitalization entered into the Serbian banking industry, with two banks (Telenor Banka and mts Banka) which are exclusively specialized in mobile banking. In banking industry, Telenor Banka entered first, after acquisition by Belgium KBC bank, and put the main focus on 
providing sophisticated services from the area of digital banking. Innovative approach in banking industry implemented in Telenor Banka is designed in the manner that physical presence of the client is not necessary; already clients have the numerous modern services adjusted to the new, digital age. It means that Telenor Banka made possible for the clients to satisfy their needs via application, which is available on smartphones or desktop computers (Mirković \& Lukić, 2015).

Described innovation made by Telenor Banka induced the reaction of domestic telecommunication operator Telekom, which entered on the Serbian banking market by acquisition of Dunav bank and formed new Mts Banka with a very similar range of services to Telenor Banka. Arising competition in Serbian banking market in the area of digitalization should make banking services cheaper in the future (some of them would be free of charge), while the sources of profit would lie in additional or consulting services. It should be noted that entrance of Telenor and Mts is a pioneer venture in the digitalization sphere and those two banks are not among larger players on Serbian banking market. Namely, the aggregate market share of those two banks, measured by the portion of their assets in total assets of Serbian banking industry, amounts only to $0.7 \%$ out of RSD $3.774,1$ billion at end of December 2018 (National bank of Serbia, 2019). Globally, banks are more than interested in digital transformation and they made a significant turnover in business orientation toward digital transformation.

In cooperation with the company "Saga doo Beograd", Raiffeisen bank has developed a completely new and unique banking service on the domestic market: a platform for communication betwenclients and the bank, based on artificial intelligence. It is a software solution that is symbolically called Rea (abbreviation from: Raiffeisen Electronic Assistant), with a specially designed android-like female figure as an avatar. Users, clients of Raiffeisen Bank, as well as those who are still not, can use all of the platform's capabilities in a very simple way, sending the message to Rea (or Raiffeisen Bank) through the most common channels of communication: Facebook Messenger or Viber.

In this way they can ask any questions about the services and products of the bank, find the nearest branch and ATM or get some other relevant support, 24 hours / 7 days a week, very quickly - using their mobile phones or computers. Unlike other communication solutions that already exist on the Serbian market, based on the so-called "decision tree", the Raiffeisen Bank solution is known as "enterprise bot", which is based on artificial intelligence and a complete understanding of the natural language. The conversation between Rea and the client takes place in Serbian or English, interactively and resembles communication between two people (Raiffeisen Bank, 2019).
It is worth a mention that in October 2018, the National Bank of Serbia launched IPS (Instant Payments Serbia) system, which is the modern, very operational and efficient system of instant payments. In this system, it is possible to transfer up to RSD 300,000 per transaction in just several seconds, after which the payee will have those funds available (National bank of Serbia, 2018).

\section{BANKING IN THE DIGITAL AGE: HOW DBS BANK EMBRACED DIGITAL TRANSFORMATION}

It is clear that banking is reshaped by new digital technologies, while banks which adopt those technologies are called digital banks. According to Caicedo (2019) digital banks should be classified into following four types:

1. New banks - which possess banking licenses and act as direct competitors with same offer as traditional banks;

2. Neo banks - banks without licenses, which act as partners with financial institutions in offering services;

3. Beta banks - are joint ventures (subsidiaries) of existing banks that offer limited services to a broader consumer base; and

4. Non-banks - are not linked to traditional banks and they rather operate on apart from them providing services uniquely.

As digital banking develops further, it is more likely that digital banking market will become saturated. Consequently, it will lead to emergence of new digital banks and simultaneously changing the focus of traditional banks on more flexible and digitalized services in their offer. Certain financial institutions primarily recognized the above mentioned opportunities and used them to obtain the comparative advantage on the digital market. An illustrative example is DBS, the most successful financial services group in Asia, with a large network and presence in over 18 markets (DBS Bank Ltd., 2019).

DBS started digital transformation in 2014, quite earlier than their main competitors. Due to orientation on digital transformations in the early stage, DBS became a global leader. Their achievements are reflected in development of extensive digital transformation programs, which supports digital journey and culture change with adequate measurement methodology (DBS Bank Ltd., 2018). DBS re-architected their technology infrastructure to be cloud-native, so $66 \%$ of open systems were cloud-ready in 2017, while at the end of 2018, this had risen to over $80 \%$. DBS become customercentric bank and for that purpose DBS changed its motto to "Live more, Bank less", which reflects beliefs that in the digital era customer should spend more time without direct involvement with banks and their procedures. DBS launched Digibank in India, which set high standards in the field of mobile banking. Digibank provides unique financial solutions when it comes to opening saving accounts. 
Their applications are user friendly, so users could simply create an account and verify their details.

The above described example of the most successful digital bank in the world in the past few years, clearly points out how banking industry experiences dramatic changes nowadays. Automation, robotics, data and data analytics are being used to make intelligent decisions.

\section{THE IMPACT OF DIGITAL TRANSFORMATION ON BANKING IN THE FUTURE}

In the world of increasing number of competitors, banking industry overall will become more strategically focused to answer on prospective consumer expectations. The FinTech Times (2019) made banking predictions for 2020:

- Significant reduction of fixed cost induced by existence of physical branches and their replacement with some other formats, e.g. „branches” in coffee shops;

- Digital customer experience will be in the center of bank's focus;

- Consumer will minimize the cash usage and real wallets will be replaced with mobile payments;

- Blockchain and Internet of Things (IoT) will prevail in banking interactions, but it will raise the issue of cyber security; and

- Smartphones will dominate service delivery and interaction.

One of the most important changes which digitalization brings is the adjustment process and transformation of organizational structure, business processes, employees etc. Digitalization will make many administrative positions and routine jobs unnecessary. On the other hand, besides existing risk that some employees will lose their jobs, there will also be new jobs that require experts from different profiles who are familiar with digital technologies.

To summarize what represent the future of banking digital transformation we can use words of Nikola Tesla: "Let the future tell the truth, and evaluate each one according to his work and accomplishments. The present is theirs; the future, for which I have really worked, is mine". We strongly believe that digital transformation will reshape the banking industry in future.

\section{CONCLUSION}

Among the most important factors which affect the success of digital transformation are agility and flexibility of the organization. Specifics of digital tranformation could be analyzed through comparative analysis between banking industry and other industries. However, digital transformation bears essential changes in business opera- tions and delivering services to customers. Organizations should identify and response on possibilities and risks of digitalization, as well asto quickly adjust to different markets and business conditions. In the center of digital transformation is a mindset shift, which puts the emphasis on a more holistic view of customer financial health. It is crucial for banks to rethink how they engage with customers at every interaction, from marketing and customer acquisition through on-boarding, product setup, to payments and transactions.

Digital transformation reshapes banking world in various aspects. Changes toward digitalization have affected the labor in banking industry, periodically resulting in reduction of employees' number. On the other hand, there is an increasing demand for Data Scientists, Data Engineers, Data Architect, Chief Data Officer, Chief Analytics Officer etc. with long lasting banking experience. The banking industry is a data-driven industry, where regulatory requirements enforces banks to store a lot of transaction data. One of the greatest challenges for banks is to translate the bulk of data into meaningful information.

Digital technologies provide significant opportunities for banks to be better than their competition and to provide a higher level of service to customers. Using digital technologies creates added value to bank's business and becomes a source of competitive advantage in satisfying customers' needs. In the paper, the case of the leading digital bank in the world, Singapore-based DBS banks, is presented, which successfully implemented digital transformation into banking business and obtained the status of the banking leader in this growing segment.

\section{LITERATURE}

1. Andriole, S., Cox, T., \& Khin, K. (2018). The Innovator's Imperative: Rapid Technology Adoption for Digital Transformation. Boca Raton: CRC Press. Taylor \& Francis Group.

2. Bankewitz, M., Aberg, C., \& Teuchert, C. (2016). Digitalization and Boards of Directors: A New Era of Corporate Governance? Business and Management Research, 5(2), 58-69.

3. Caicedo, D. (2019). The Types of Digital Banks and What They Mean for Business. Available at: https://www.business.com/articles/types-digital-banks/ (12.07.2019)

4. DBS Bank Ltd. (2018). DBS Group Holdings Ltd. - Annual Report 2018. Available at: https://www.dbs.com/ annualreports/2018/downloads/dbs-annual-report-2018. $\operatorname{pdf}(12.07 .2019)$

5. DBS Bank Ltd. (2019). Newsroom - the latest on DBS. Available at: https://www.dbs.com/newsroom/DBS_ named_Worlds_Best_Bank_by_Euromoney_magazine (12.07.2019)

6. Dudić, B., Drahošová, M., Lukić, J., Dudić, Z., Smolen \& Mirković, V. (2018). Counterparty Credit Risk Closure: 
Challenges in Big Data Era. IBIMA - Innovation Management and Education Excellence through Vision 2020, 2441-2453., Milano: April 25-26, 2018.

7. Herbert, L. (2017). Digital Transformation: Build your Organizations Future for the Innovation Age. Bloomsbury Publishing Plc.

8. Hughes, J. (2017). What a digital organization looks like. Available at: https://medium.com/doteveryone/what-adigital-organisation-looks-like-82426a210ab8 (18.01.2019)

9. Hyatt, J. (2018). The Revolution Will Be Digitized. Perspectives from CFO Research. Field Notes: CFO, April / May, 46-47.

10. Lukić, J. (2016). The New Job Positions for Working with Big Data Technologies and Their Placement in Companies Worldwide: Evidence From Empirical Research. Facta Universitatis, Series: Economics and Organization, 13(3), 301-312.

11. Lukić, J. (2017). Transformation of Coordination Mechanisms in Companies due to New Technologies: Evidence From Empirical Research. Ekonomske teme, 55(3), 421-436.

12. Lukić, J., Salkić, H. \& Ostojić, B. (2018). New Job Positions and Recruitment of Employees Shaped by Blockchain Technologies. Fourt International Scientific Conference LIMEN, 314-320., Belgrade.

13. Lukić, J. \& Mirković, V. (2018). Transformacija poslovnih procesa i upravljanja bankarskim rizicima u Big Data svetu. XXIII Internacionalni naučni skup SM 2018, Strategijski menadžment $i$ sistemi podrške odlučivanju u strategijskom menadžmentu, 137-144., Subotica: Ekonomski fakultet.

14. Mazzone, D.M. (2014). Digital or Death: Digital Transformation: The Only Choice for Business to Survive Smash and Conquer. Smashbox Consulting Inc.

15. Mirković, V. \& Lukić, J. (2015). Mobilno bankarstvo kao inovacija u sektoru finansijskih usluga. Ekonomski vidici, XX (2-3), 297-310.

16. Mirković, V., Dudić, Z. \& Dudić, B. (2016). Bankarstvo u senci kao potencijalni faktor nestabilnosti finansijskih sistema. FINIZ 2016 - Risks in contemporary business, 190 - 196., doi:10.15308/finiz-2016-190-196. Beogard: Univerzitet Singidunum.

17. Mirković, V. (2017). Uticaj finansijske tehnologije na savremeno bankarsko poslovanje. XXII Internacionalni naučni skup SM 2017, Strategijski menadžment $i$ sistemi podrške odlučivanju u strategijskom menadžmentu, 304311., Subotica: Ekonomski fakultet.

18. Mirković, V., Lukić, J., Lazarević, S. \& Vojinović, Ž. (2019). Key characteristics of the organizational structure that supports digital transformation. XXIV Internacionalni naučni skup SM 2019, Strategijski menadžment $i$ sistemi podrške odlučivanju u strategijskom menadžmentu, 255-261., Subotica: Ekonomski fakultet.

19. National bank of Serbia (2018). IPS System Goes Live. Available at: http://www.nbs.rs/internet/english/15/ mediji/vesti/20181022.html (17.07.2019)
20. National bank of Serbia (2019). Financial Statements. Available at: http://www.nbs.rs/internet/english/50/50_5. html (16.07.2019)

21. PricewaterhouseCoopers (2013). Digitale Transformation - der größte Wandel seit der industriellen Revolution, Frankfurt.

22. Raiffeisen Bank (2019). Available at: https://www.raiffeisenbank.rs/digitalne-usluge/rea-elektronska-asistentkinja/ (17.07.2019)

23. Stone, S. M. (2019). Digitally Deaf: Why Organizations Struggle with Digital Transformation. Switzerland: Springer Nature Switzerland AG.

24. The Fintech Times (2019). 2020 Banking Predictions. Available at: https://thefintechtimes.com/2020-bankingpredictions/ (17.07.2019)

25. Westerman, G., Calméjane, C. \& Bonnet, D. (2011). Digital transformation: A roadmap for billion-dollar organizations. MIT Center for Digital Business and Capgemini Consulting, 1- 68 . 